\title{
ISOLASI DAN ELUSIDASI STRUKTUR SENYAWA DARI EKSTRAK BAWANG DAYAK SERTA UJI AKTIVITAS ANTIBAKTERINYA
}

\author{
Senda Kartika Rakainsa ${ }^{1}$, Khoirun Nisa ${ }^{2}$ \\ ${ }^{1}$ Universitas Negeri Semarang \\ ${ }^{2}$ Balai Penelitian Teknologi Bahan Alam, Lembaga Ilmu Pengetahuan Indonesia
}

\begin{tabular}{l}
\hline \hline Article Info \\
\hline Article history: \\
Received Jan 26, 2021 \\
Revised Mar 17, 2021 \\
Accepted Mar 26, 2021
\end{tabular}

Keywords:

Dayak Onion

Antibacterial

Isolation

Hongconin

\begin{abstract}
Antibacterial activity screening was carried out on 10 species of medicinal plants that have been empirically used in traditional medicine in Indonesia, including the bulb of dayak onion (Eleutherine bulbosa), ki tolod herb (Isotoma longiflora), fruit of ketepeng cina (Cassia alata), and bluntas leaves (Pluchea indica). Based on the results of antibacterial activity screening, the extract of dayak onion (Eleutherine bulbosa) showed the most prominent antibacterial activity against Bacillus subtilis and Staphylococcus aureus at extract concentrations of 200 and $100 \mu \mathrm{g} / \mathrm{ml}$, and against Klebsiella pneumoniae at an extract concentration of $200 \mu \mathrm{g} / \mathrm{ml}$. Purification and isolation of compounds and antibacterial activity assay were carried out to determine which compounds were responsible for the antibacterial activity of dayak onion. From the purification and isolation of the bioactive compound using MPLC, column chromatography, and preparative TLC, an isolate compound (4 mg) was isolated. The compound was analyzed using LR-EIMS and 1D-2D NMR, and was subsequently identified as Hongconin. The antibacterial activity test of dayak onion extract and isolated compounds showed that the extract of dayak onion exhibited moderate antibacterial activity against B. subtilis, S. aureus, and K. pneumoniae, indicated by the MIC value ranging from 100-200 $\mu \mathrm{g} / \mathrm{ml}$. Meanwhile, the isolate compound (Hongconin) exerted antibacterial activity which is classified as weak against all types of pathogenic bacteria tested, indicated by the MIC value of $>200 \mu \mathrm{M}$.
\end{abstract}

This is an open access article under the CC BY-SAlicense.

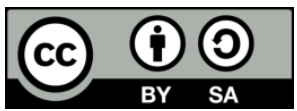

\section{Corresponding Author:}

Senda Kartika Rakainsa,

Program Studi Farmasi, Fakultas Matematika dan Ilmu Pengetahuan Alam,

Universitas Negeri Semarang,

Jl. Raya Sekaran, Kel. Sekaran, Kec. Gunungpati, Kota Semarang - Jawa Tengah.

Email: sendakartika@mail.unnes.ac.id

\section{INTRODUCTION}

Menurut (Ayu Dwi Putri, 2017) Kehamilan dapat menyebabkan perubahan fisik, psikis dan Penyakit infeksi yang disebabkan oleh bakteri, jamur, virus, dan parasit merupakan masalah kesehatan yang masih menjadi tantangan di seluruh dunia, terlepas dari perkembangan dunia medis dan pengobatan yang amat 
pesat. Akibat yang disebabkan oleh penyakit infeksi tersebut dirasakan sangat besar terutama di Negara berkembang seperti Indonesia, dikarenakan terbatasnya jenis pengobatan yang efektif, terbatasnya akses kesehatan bagi masyarakat kalangan menengah ke bawah, serta meningkatnya kasus resistensi antibiotik [1]. Di Indonesia sendiri, penyakit akibat infeksi bakteri seperti diare, pneumonia, ISPA, dan TBC masih menjadi masalah kesehatan yang mendesak untuk ditangani. Bahkan, penyakit infeksi menjadi penyumbang kematian pada bayi dan anak-anak. Tahun 2019, pneumonia dan diare masih menjadi masalah utama yang menyebabkan 979 kematian (pneumonia) dan 746 kematian (diare) [2].

Kemunculan bakteri patogen yang resisten kini semakin meningkat, sehingga membuat bakteri patogen tersebut menjadi tidak sensitif terhadap berbagai golongan antibiotik. Hal ini mendorong penemuan antibiotik baru, yang mana telah menjadi menjadi fokus baru para peneliti di bidang kedokteran dan farmasi [3]. Selain sumber mikroorganisme, metabolit sekunder dari tanaman mulai dilirik sebagai sumber senyawa antibakteri yang baru. Tanaman mengakumulasikan senyawa metabolit sekunder dengan aktivitas antibakteri, seperti alkaloid, kumarin, isoflavonoid, quinone, tannin, and terpen. Senyawa-senyawa ini bertanggung jawab atas mekanisme pertahanan tanaman terhadap mikroba patogen dan herbivora yang ada di sekitarnya [4]. Biodiversitas flora di Indonesia, terutama keragaman jenis tanaman obat yang digunakan untuk pengobatan tradisional sangatlah tinggi. Namun demikian, penelitian tentang aktivitas biologis tanaman obat masih terbatas. Berdasarkan fakta tersebut, maka diperkirakan potensi tanaman obat di Indonesia yang menyimpan aktivitas antibakteri sangat besar dan masih perlu untuk digali.

Pada penelitian ini, dilakukan skrining aktivitas antibakteri terhadap 10 spesies tanaman obat yang secara empiris telah digunakan dalam pengobatan tradisional di Indonesia. Khasiat empiris dari tanamantanaman tersebut sangat beragam, beberapa di antaranya mengarah pada potensi antibakteri, seperti herba ki tolod (Isotoma longiflora), buah ketepeng cina (Cassia alata), dan daun bluntas (Pluchea indica) untuk pengobatan berbagai penyakit kulit dan infeksi mata [5-7]. Selain itu, kandungan metabolit sekunder dari tanaman-tanaman tersebut seperti alkaloid, terpen, tannin, saponin, flavonoid, dan fenolik telah terbukti mempunyai aktivitas antibakteri terhadap bakteri patogen [8-11]. Penelitian ini bertujuan untuk menyelidiki tanaman obat yang berpotensi sebagai agen antibakteri, serta melakukan isolasi senyawa yang bertanggung jawab terhadap efek antibakteri tanaman tersebut. Senyawa isolat diuji aktivitas antibakterinya terhadap 4 jenis bakteri patogen, yaitu Bacillus subtilis, Staphylococcus aureus, Escherichia coli, dan Klebsiella pneumonia.

\section{RESEARCH METHOD}

Alat yang digunakan dalam penelitian ini antara lain alat MPLC/Medium Pressure Liquid Chromatography (Buchi Labortechnik AG C-615). Silica gel (40-50 $\mu \mathrm{m}$, Kanto Chemical Co., Inc., Tokyo, Jepang) digunakan untuk kromatografi kolom. KLT untuk analisis dan KLT-preparatif dilakukan menggunakan plat silika 60F254 (Merck). KLT preparatif dilakukan dengan chamber KLT (Yazawa, Tokyo, Japan) yang telah dijenuhkan dengan fase gerak. Visualisasi KLT dengan lampu UV 254 dan $366 \mathrm{~nm}$ (Yamazen). Spektra massa dari senyawa isolat diambil dengan LR-EIMS/Low Resolution-Electron Impact Mass Spectrometer (Shimadzu). Spektra NMR diambil dengan JEOL JNM-ECA500II Spectrometer dengan Tetrametilsilane sebagai standar internal (Wako Pure Chemical Industries). Serbuk simplisia tanaman obat yaitu daun dandang gendis, buah ketepeng cina, herba alang-alang, daun patikan kebo, daun daruju, umbi bawang dayak, daun ungu, daun dadap, daun bluntas, dan herba ki tolod diperoleh dari distributor simplisia di daerah Sleman, Yogyakarta. Strain bakteri Bacillus subtilis NBRC 13719, Staphylococcus aureus NBRC 100910, Escherichia coli NBRC 102203, dan Klebsiella pneumoniae NBRC 14940, didapat dari National Institute of Technology and Evaluation (NITE, Tokyo, Jepang).

\section{Skrining Antibakteri}

Sepuluh jenis tanaman obat diambil masing-masing sebanyak $20 \mathrm{~g}$ untuk dibuat ekstrak kloroformnya. Pembuatan ekstrak dilakukan dengan metode maserasi pada suhu kamar dengan bantuan sonikasi.Masing-masing ekstrak dari tanaman kemudian dilakukan skrining aktivitas antibakterinya terhadap 2 jenis bakteri Gram positif, yaitu Bacillus subtilis NBRC 13719 dan Staphylococcus aureus NBRC 100910, serta bakteri Gram negatif yaitu Klebsiella pneumoniae NBRC 14940 dan Escherichia coli NBRC 102203, menggunakan metode mikrodilusi [12]. Bakteri diinokulasikan pada media agar YP (yeast-polypeptone) dan diinkubasi pada suhu $37^{\circ} \mathrm{C}$ selama 12 jam. Bakteri kemudian dipindahkan ke media cair YP (tanpa agar) dan diinkubasi pada suhu $37^{\circ} \mathrm{C}$ selama 12 jam dengan penggojogan pada alat shaker. Ekstrak tanaman dilarutkan menggunakan DMSO dengan konsentrasi masing-masing $10 \mathrm{mg} / \mathrm{ml}$. Media YP cair yang berisi bakteri dipindahkan ke 96-well plate dan larutan ekstrak diaplikasikan ke dalamnya. Media dan sampel kemudian didilusi menjadi dua jenis konsentrasi $(200 \mu \mathrm{g} / \mathrm{mldan} 100 \mu \mathrm{g} / \mathrm{ml})$. Ampicillin dan Kanamycin digunakan sebagai kontrol positif dan kontrol negatifnya adalah DMSO. Plate diinkubasi selama 24 jam dan aktivitas penghambatan pertumbuhan bakteri diamati secara visual dengan penambahan $50 \mu \mathrm{L}$ larutan MTT 
(konsentrasi $5 \mathrm{mg} / \mathrm{ml}$ dalam isopropanol-HCl) ke dalam masing-masing sumuran diikuti dengan inkubasi selama 1 jam. Percobaan dilakukan dengan 3 kali replikasi. Ekstrak yang dipilih untuk dilakukan isolasi dan purifikasi adalah ekstrak yang menunjukkan penghambatan pertumbuhan koloni bakteri yang dapat diamati secara visual (warna kuning jernih), baik pada konsentrasi 200 mg/ml maupun $100 \mathrm{mg} / \mathrm{ml}$.

\section{Ekstraksi Bawang Dayak}

Sampel Bulbus (umbi lapis) Bawang Dayak (Eleutherine bulbosa) yang telah dikeringkan sebanyak 1,5 kg diekstraksi menggunakan pelarut kloroform sebanyak 2 L dengan bantuan sonikasi selama 90 menit di suhu ruang. Kemudian dilakukan remaserasi sebanyak 2 kali untuk memperoleh hasil ekstrak yang lebih optimal. Ekstrak disaring dengan corong vakum dan diuapkan menggunakan rotary evaporator untuk memperoleh ekstrak kental.

\section{Isolasi Senyawa dan Elusidasi Struktur Senyawa Isolat}

Ekstrak Bawang Dayak (23.5 g) dipisahkan dengan MPLC fase normal (silica gel; 40-50 $\mu \mathrm{m}, 1.85$ $\mathrm{kg}$; kolom 100x460 mm; flow rate $=25 \mathrm{ml} / \mathrm{menit}$ ) menggunakan kombinasi pelarut $\mathrm{n}$-heksana: etil asetat (100:0-0-100) sehingga menghasilkan 18 fraksi. Fraksi 7 (bobot $51 \mathrm{mg}$; persentase n-heksana: etil asetat=70:30) kemudian dipisahkan dengan kolom kromatografi fase normal menggunakan pelarut $n$ heksana: etil asetat=5:1 sehingga menghasilkan 4 subfraksi. Sub fraksi 4 (10 mg) dimurnikan dengan KLT preparatif (n-heksana: etil asetat=1:1) menghasilkan suatu senyawa isolat (4 $\mathrm{mg}$ ), kemudian dianalisis strukturnya dengan 1D dan 2D NMR serta LR-EIMS.

\section{Uji Aktivitas Antibakteri Ekstrak Bawang Dayak dan Senyawa Isolat}

Ekstrak bawang dayak aktivitas antibakterinya terhadap 2 jenis bakteri Gram positif, yaitu Bacillus subtilis NBRC 13719 dan Staphylococcus aureus NBRC 100910, serta bakteri Gram negatif yaitu Klebsiella pneumoniae NBRC 14940, menggunakan metode mikrodilusi [12]. Larutan stok untuk ekstrak (10 mg/ml dalam DMSO) dan larutan stok senyawa isolat ( $5 \mathrm{mM}$ dalam DMSO) didilusi menjadi beberapa konsentrasi (konsentrasi ekstrak: 200, 100, 50, 25, dan $12.5 \mu \mathrm{g} / \mathrm{ml}$; konsentrasi senyawa isolat: 200, 100, 50, 25, dan 12.5 $\mu \mathrm{M}$ ) dalam media YP berisi bakteri pada 96-well plates untuk mencari nilai KHM (Kadar Hambat Minimum). Ampicillin dan Kanamycin digunakan sebagai kontrol positif dan DMSO sebagai kontrol negatif. Plate diinkubasi selama 24 jam dan aktivitas penghambatan pertumbuhan bakteri diamati secara visual dengan penambahan $50 \mu \mathrm{L}$ larutan MTT (konsentrasi $5 \mathrm{mg} / \mathrm{ml}$ dalam isopropanol-HCl) ke dalam masingmasing sumuran diikuti dengan inkubasi selama 1 jam. Percobaan dilakukan dengan 3 kali replikasi. Percobaan dilakukan dengan 3 kali replikasi. Nilai KHM dari sampel didefinisikan sebagai konsentrasi terendah yang dapat menghambat pertumbuhan bakteri secara keseluruhan setelah diinkubasi selama $37^{\circ} \mathrm{C}$ selama 24 jam. Penghambatan pertumbuhan bakteri diamati secara visual dengan melihat sumuran yang berwarna kuning jernih.

\section{RESULTS AND ANALYSIS}

\subsection{Hasil}

\section{Skrining Aktivitas Antibakteri}

Skrining aktivitas antibakteri dilakukan terhadap 10 spesies tanaman obat menggunakan metode mikrodilusi terhadap bakteri-bakteri patogen, yaitu Bacillus subtilis, Staphylococcus aureus, Escherichia coli, dan Klebsiella pneumoniae. Berdasarkan hasil skrining aktivitas antibakteri, ekstrak umbi bawang dayak (Eleutherine bulbosa) menunjukkan aktivitas antibakteri paling dominan terhadap B. subtilis dan $S$. aureus pada konsentrasi ekstrak 200 dan $100 \mu \mathrm{g} / \mathrm{ml}$, serta terhadap K.pneumoniae pada konsentrasi ekstrak 200 $\mu \mathrm{g} / \mathrm{ml}$ (Tabel 1). Beberapa ekstrak tanaman lain menunjukkan aktivitas antibakteri terhadap K.pneumoniae, seperti buah ketepeng cina, daun patikan kebo, daun daruju, daun dadap, dan herba ki tolod. Namun, tidak ada sampel ekstrak yang menunjukkan aktivitas antibakteri terhadap E.coli. Ditinjau dari aktivitas antibakterinya, maka dipilih umbi bawang dayak (E. bulbosa) untuk selanjutnya dilakukan purifikasi dan isolasi senyawa bioaktifnya.

Tabel 1. Hasil Skrining Antibakteri 10 Spesies Tanaman Obat Indonesia

\begin{tabular}{cccccc}
\hline No & Nama tanaman & B. subtilis & S.aureus & K.pneumoniae & E.coli \\
\hline 1 & $\begin{array}{c}\text { Daun dandang gendis } \\
\text { (Clinacanthus nutans) }\end{array}$ & - & - & - & - \\
\hline 2 & $\begin{array}{c}\text { Buah ketepeng cina } \\
(\text { Cassia alata })\end{array}$ & - & - & + & - \\
\hline 3 & $\begin{array}{c}\text { Herba alang-alang } \\
(\text { Imperata cylindrica) }\end{array}$ & - & - & - & - \\
\hline
\end{tabular}




\begin{tabular}{|c|c|c|c|c|c|}
\hline 4 & $\begin{array}{l}\text { Daun patikan kebo } \\
\text { (Euphorbia hirta) }\end{array}$ & - & - & $\begin{array}{c}+ \\
+ \\
(200 \mu \mathrm{g} / \mathrm{ml})\end{array}$ & - \\
\hline 5 & $\begin{array}{c}\text { Daun daruju } \\
\text { (Acanthus ilicifolium) }\end{array}$ & - & - & $\begin{array}{c}+ \\
(200 \mu \mathrm{g} / \mathrm{ml})\end{array}$ & - \\
\hline 6 & $\begin{array}{l}\text { Umbi bawang dayak } \\
\text { (Eleutherine bulbosa) }\end{array}$ & $\begin{array}{c}+ \\
(200 \& 100 \\
\mu \mathrm{g} / \mathrm{ml})\end{array}$ & $\begin{array}{c}+ \\
(200 \\
\& 100 \\
\mu \mathrm{g} / \mathrm{ml})\end{array}$ & $\begin{array}{c}+ \\
(200 \mu \mathrm{g} / \mathrm{ml})\end{array}$ & - \\
\hline 7 & $\begin{array}{c}\text { Daun ungu } \\
\text { (Graptophylum pictum) }\end{array}$ & - & - & - & - \\
\hline 8 & $\begin{array}{c}\text { Daun dadap } \\
\text { (Erythrina lithosperma) }\end{array}$ & - & - & $\begin{array}{c}+ \\
(200 \mu \mathrm{g} / \mathrm{ml}) \\
\end{array}$ & - \\
\hline 9 & $\begin{array}{c}\text { Daun bluntas } \\
\text { (Pluchea indica) }\end{array}$ & - & - & - & - \\
\hline 10 & $\begin{array}{c}\text { Herba ki tolod } \\
\text { (Isotoma longiflora) }\end{array}$ & - & - & $\begin{array}{c}+ \\
(200 \mu \mathrm{g} / \mathrm{ml})\end{array}$ & - \\
\hline
\end{tabular}

\section{Ekstraksi dan Isolasi Senyawadari E.bulbosa}

Simplisia umbi lapis (bulbus) dari E.bulbosa yang dikeringkan diekstraksi dengan kloroform untuk menarik senyawa metabolit sekunder yang ada di dalamnya. Ekstraksi dilakukan dengan metode maserasi pada suhu kamar diikuti dengan dua kali remaserasi supaya memperoleh rendemen ekstrak yang optimal. Dari hasil maserasi diperoleh ekstrak seberat $23.5 \mathrm{~g}$ yang kemudian dipisahkan dengan MPLC menggunakan kombinasi pelarut n-heksana:etil asetat (100:0-0-100). Fraksi 7 (persentase n-heksana: etil asetat=70:30) kemudian dipisahkan dengan kolom kromatografi fase normal menggunakan pelarut n-heksana: etil asetat=5:1 diikuti dengan KLT preparatif (n-heksana: etil asetat=1:1) menghasilkan suatu senyawa isolat (4 $\mathrm{mg}$ ). Senyawa tersebut selanjutnya dielusidasi strukturnya dengan bantuan analisis LR-EIMS serta 1D dan 2D NMR.

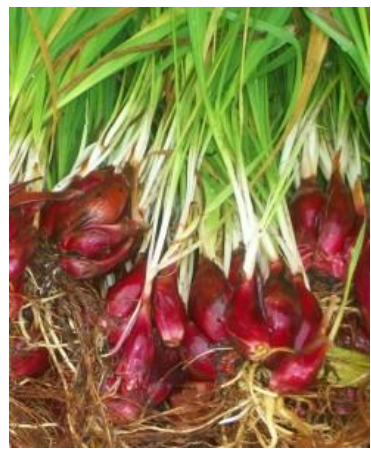

Gambar 1. Eleutherine bulbosa Mill.

Senyawa isolat berwujud padatan kuning dengan bobot molekul 288 yang dikonfirmasi dari hasil spektra LR-EIMS yang menunjukkan peak ion pada $\mathrm{m} / \mathrm{z} 288[\mathrm{M}+\mathrm{Na}]^{+}$. Rumus molekulnya diperoleh $\mathrm{C}_{16} \mathrm{H}_{16} \mathrm{O}_{5}$ dari deduksi data ${ }^{13} \mathrm{C}$ NMR. Data ${ }^{1} \mathrm{H}$ NMR menunjukkan keberadaan dua gugus hidroksil pada pergeseran kimia $8.96 \mathrm{ppm}(\mathrm{s})$ dan $12.81 \mathrm{ppm}(\mathrm{s})$, tiga proton aromatik pada $7.01 \mathrm{ppm}(\mathrm{d}), 7.38 \mathrm{ppm}(\mathrm{t})$, dan $8.05 \mathrm{ppm}(\mathrm{d})$, satu proton dari gugus metoksi pada $4.02 \mathrm{ppm}(\mathrm{s})$, dan dua proton metin pada $4.69 \mathrm{ppm}(\mathrm{q})$ dan $5.50 \mathrm{ppm}(\mathrm{q})$. 


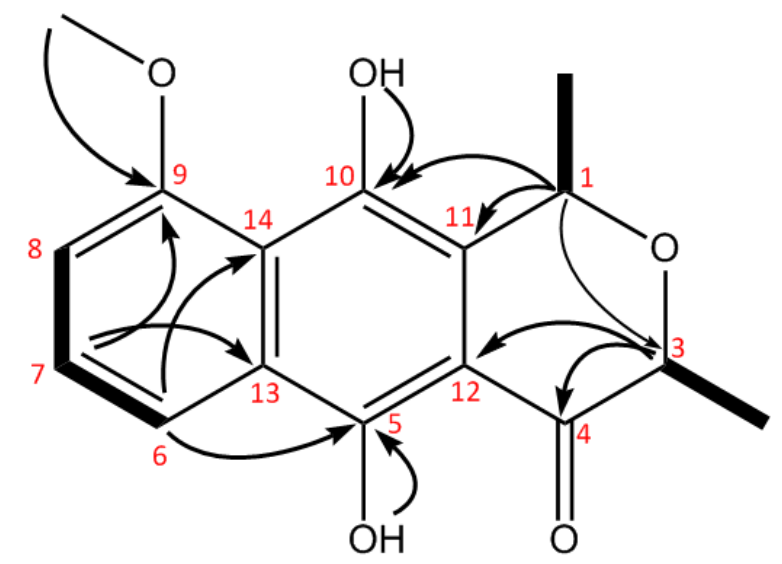

Gambar 2. Korelasi HMBC (ditunjukkan dengan anak panah) dan COSY (garis tebal) dari Senyawa Isolat (Hongconin)

Analisis 2D NMR menunjukkan korelasi HMBC yang teramati antara H-6 dengan C-14, H-7 dengan C-13, serta H-6 dengan C-5, yang mengindikasikan adanya struktur inti naftalena (Gambar 2). Proton singlet dari gugus metoksi pada 4.02 ppm merupakan proton pada posisi C-9, berdasarkan korelasi HMBC antara proton tersebut dengan C-9. Keberadaan proton fenolik pada C-5 dan C-10 didukung dengan korelasi dari proton 5-OH dengan C-5 dan proton 10-OH dengan C-10. Korelasi dari proton metil 1-Me dengan C-1 dan 3Me dengan C-3 mengonfirmasikan bahwa terdapat dua gugus metil yang terikat masing-masing pada C-1 dan C-3. Hal tersebut juga diperkuat dengan korelasi COSY antara proton metin pada $\mathrm{H}-1$ dengan proton metil pada C-1, serta proton metin pada H-3 dengan proton metil pada C-3. Korelasi HMBC antara H-1 dengan C3, serta pergeseran kimia pada C-1 dan C-3 ( $\delta \mathrm{c} 69.5$ dan $67.4 \mathrm{ppm})$ mengindikasikan keberadaan oxygenated carbon. Keberadaan karbon karbonil diketahui dari pergeseran kimia C-4 pada 202.9 ppm. Dari hasil analisis 1D dan 2D NMR, serta perbandingan data spektra NMR dengan referensi penelitian sebelumnya (Tabel 2), maka senyawa isolat tersebut diidentifikasi sebagai suatu turunan naftalena, yaitu $(1 R, 3 R) 5,10$-Dihydroxy-9methoxy-1, 3-dimethyl-1H-naphtho [2,3-c] pyran-4(3H)-one, atau yang dikenal dengan nama lain Hongconin $[13,14]$.

Tabel 2. Perbandingan Spektra NMR dari Senyawa Isolat dan Referensi

\begin{tabular}{ccccc}
\hline Posisi & $\boldsymbol{\delta}_{\mathbf{C}}$ isolat & $\boldsymbol{\delta}_{\mathbf{C}}$ ref. & $\boldsymbol{\delta}_{\mathbf{H}}$ isolat & $\boldsymbol{\delta}_{\mathbf{H}}$ ref* \\
\hline 1 & 69.5 & 69.5 & $4.69(\mathrm{q}, 6.4)$ & $4.69(\mathrm{q}, 6.4)$ \\
\hline 3 & 67.4 & 67.4 & $5.50(\mathrm{q}, 6.7)$ & $5.48(\mathrm{q}, 6.7)$ \\
\hline 4 & 203.3 & 202.9 & - & - \\
\hline 5 & 154.4 & 153.4 & - & - \\
\hline 6 & 118.0 & 118.1 & $8.05(\mathrm{~d}, 8.5)$ & $8.04(\mathrm{~d}, 8.5)$ \\
\hline 7 & 125.4 & 125.4 & $7.38(\mathrm{t}, 8.2)$ & $7.38(\mathrm{t}, 8.2)$ \\
\hline 8 & 109.1 & 109.1 & $7.01(\mathrm{~d}, 7.9)$ & $7.01(\mathrm{~d}, 7.9)$ \\
\hline 9 & 155.7 & 155.7 & - & - \\
\hline 10 & 139.4 & 139.4 & - & - \\
\hline 11 & 107.8 & 107.8 & - & - \\
\hline 12 & 119.6 & 119.6 & - & - \\
\hline 13 & 125.9 & 126.0 & - & $1.53(\mathrm{~d}, 6.4)$ \\
\hline 14 & 120.9 & 120.9 & - & $1.63(\mathrm{q}, 6.7)$ \\
\hline $1-\mathrm{Me}$ & 17.4 & 16.3 & $1.54(\mathrm{~d}, 6.4)$ & $12.82(\mathrm{~s})$ \\
\hline $3-\mathrm{Me}$ & 17.9 & 17.4 & $1.64(\mathrm{q}, 6.7)$ & $8.98(\mathrm{~s})$ \\
\hline $5-\mathrm{OH}$ & - & - & $12.81(\mathrm{~s})$ & $4.07(\mathrm{~s})$ \\
\hline $10-\mathrm{OH}$ & - & - & $8.96(\mathrm{~s})$ & $4.02(\mathrm{~s})$ \\
\hline $9-\mathrm{OMe}$ & 56.4 & 56.4 & $\mathrm{Cl}$ & \\
\hline
\end{tabular}

$\delta_{\mathrm{C}}:{ }^{13} \mathrm{C}\left(\mathrm{ppm}, 100 \mathrm{MHz}, \mathrm{CDCl}_{3}\right) . \delta_{\mathrm{H}}:{ }^{1} \mathrm{H}\left(\mathrm{ppm}, 500 \mathrm{MHz}, \mathrm{CDCl}_{3}\right)$, Coupling constant $J(\mathrm{~Hz})$

*Referensi dari Fernandes \& Chavan (2010)

\section{Uji Aktivitas Antibakteri}

Untuk mengetahui aktivitas antibakteri ekstrak bawang dayak serta senyawa isolatnya (Hongconin) maka dilakukan uji aktivitas antibakteri dengan tujuan mencari nilai KHM (Kadar Hambat Minimum) dengan hasil ditunjukkan pada Tabel 3. 
Tabel 3. Hasil Uji Aktivitas Antibakteri Ekstrak Bawang Dayak dan Senyawa Isolat

\begin{tabular}{|c|c|c|c|c|c|}
\hline \multirow[t]{2}{*}{ No } & \multirow[t]{2}{*}{ Sampel } & \multicolumn{4}{|c|}{ Nilai KHM } \\
\hline & & B. subtilis & S.aureus & K.pneumoniae & E.coli \\
\hline 1 & Ekstrak bawang dayak & $100 \mu \mathrm{g} / \mathrm{ml}$ & $100 \mu \mathrm{g} / \mathrm{ml}$ & $200 \mu \mathrm{g} / \mathrm{ml}$ & $>200 \mu \mathrm{g} / \mathrm{ml}$ \\
\hline 2 & Senyawa Isolat (Hongconin) & $>200 \mu \mathrm{M}$ & $>200 \mu \mathrm{M}$ & $>200 \mu \mathrm{M}$ & $>200 \mu \mathrm{M}$ \\
\hline 3 & Ampicillin (kontrol positif) & $<0.2 \mu \mathrm{M}$ & $<0.2 \mu \mathrm{M}$ & - & - \\
\hline 4 & Kanamycin (kontrol positif) & - & - & $5.2 \mu \mathrm{M}$ & $10.4 \mu \mathrm{M}$ \\
\hline
\end{tabular}

\subsection{Pembahasan}

Skrining aktivitas antibakteri dari 10 spesies tanaman menunjukkan bahwa tidak ada sampel tanaman yang mempunyai aktivitas antibakteri terhadap E.coli. Bakteri E.coli termasuk bakteri Gram negatif yang dikenal sulit untuk dipenetrasi oleh senyawa obat dan antibiotik. Hal ini disebabkan oleh dinding sel bakteri Gram negatif yang terdiri dari beberapa lapisan, sehingga bakteri jenis ini dikenal lebih resisten terhadap antibiotik daripada bakteri Gram positif [16].

Dari hasil penelitian ini, diketahui bahwa tanaman bawang dayak mempunyai aktivitas antibakteri. Tanaman bawang dayak telah diketahui mengandung tiga golongan besar senyawa metabolit sekunder yang telah diisolasi sebelumnya, seperti naftalena, antrakuinon, dan naftokuinon, serta senyawa lain seperti stigmasterol-3-Oß-D-glucopyranoside, kadsuric acid dan stigmasterol. Tanaman ini dilaporkan mempunyai aktivitas biologi sebagai antimikroba, antiinflamasi, antivirus, antihipertensi, dan sitotoksik, sehingga hasil penelitian ini sejalan dengan penelitian yang telah dilakukan sebelumnya [17]. Selanjutnya, purifikasi dan isolasi ekstrak bawang dayak dilakukan untuk menyelidiki kandungan senyawa yang bertanggung jawab atas efek antibakterinya, mengingat penelitian tentang aktivitas antibakteri dari senyawa bioaktif tanaman bawang dayak masih sangat terbatas. Dari proses purifikasi dan isolasi ekstrak bawang dayak, diperoleh suatu senyawa bernama Hongconin.

Senyawa ini selanjutnya diuji aktivitas antibakterinya menggunakan metode dilusi cair dikombinasikan dengan MTT untuk mengetahui nilai KHM. Nilai KHM didefinisikan sebagai konsentrasi ekstrak/senyawa yang menunjukkan penghambatan total terhadap pertumbuhan koloni bakteri [18]. Teknik dilusi yang dikombinasikan dengan metode MTT merupakan salah satu teknik yang sesuai untuk menentukan nilai KHM [19]. Prinsip reaksi MTT adalah reduksi enzimatis dari garam tetrazolium menjadi formazan pada sel bakteri yang masih hidup yang berwarna ungu kebiruan [20]. Sementara itu, pada sel bakteri yang pertumbuhannya terhambat/mati reaksi tersebut tidak terjadi sehingga teramati secara visual menunjukkan warna kuning jernih.

Uji aktivitas antibakteri ekstrak bawang dayak menunjukkan hasil ekstrak bawang dayak mempunyai aktivitas antibakteri terhadap B. subtilis, S. aureus, dan $K$. pneumonia. Hal ini sesuai dengan hasil yang ditunjukkan oleh penelitian sebelumnya bahwa ekstrak bawang dayak mempunyai aktivitas antibakteri terhadap S. aureus ATCC 23235 dan 27664, Streptococcous mutans dan S. pyogenes dengan nilai KHM bervariasi antara 120-125 $\mu \mathrm{g} / \mathrm{mL}$ [21]. Fraksi yang dipisahkan dari ekstrak bawang dayak juga terbukti menghambat pertumbuhan bakteri MRSA (Methycillin Resistant Staphylococcus aureus) dengan KHM bervariasi antara $62.5-1000 \mu \mathrm{g} / \mathrm{mL}$ [22]. Ekstrak bawang dayak dinyatakan dapat mendenaturasi sitoplasma dan mengganggu kestabilan membran serta menyebabkan kebocoran membran sel bakteri S. aureus [23].

Sementara itu, senyawa isolat (Hongconin) mempunyai aktivitas antibakteri yang tergolong lemah terhadap semua jenis bakteri pathogen yang diujikan, ditunjukkan dengan nilai KHM >200 $\mu$ M [24]. Penelitian sebelumnya menyatakan bahwa senyawa tersebut mempunyai aktivitas antibakteri terhadap $S$. aureus ATCC 27664 dengan KHM $31.25 \mu \mathrm{M}$ dan terhadap S. aureus ATCC 25923 dengan KHM $125 \mu \mathrm{M}$ [17]. Perbedaan nilai KHM antara penelitian ini dan penelitian yang telah dipublikasi sebelumnya dapat disebabkan oleh perbedaan dalam jumlah inoculum bakteri, tipe media pertumbuhan, waktu inkubasi, dan metode preparasi inoculum [25]. Namun demikian, secara umum senyawa Hongconin dapat dikategorikan mempunyai aktivitas antibakteri sedang-lemah terhadap berbagai jenis bakteri patogen. Dimungkinkan senyawa lain yang terkandung dalam ekstrak bawang dayak bertanggung jawab atas aktivitas antibakteri pada ekstrak. Oleh karena itu, penelitian tentang isolasi senyawa bioaktif dari ekstrak bawang dayak dan uji aktivitas antibakterinya perlu dikembangkan lebih jauh.

\section{CONCLUSION}

1. Sepuluh spesies tanaman obat yang diskrining aktivitas antibakterinya menunjukkan aktivitas antibakteri, di antaranya umbi bawang dayak, buah ketepeng cina, daun patikan kebo, daun daruju, daun dadap, dan 
herba ki tolod.

2. Isolasi dan elusidasi struktur senyawa bioaktifdari ekstrak bawang dayak menghasilkan senyawa isolat yang diidentifikasi sebagai Hongconin, berdasarkan analisis dengan LR-EIMS dan 1D-2D NMR.

3. Uji aktivitas antibakteri ekstrak bawang dayak dan senyawa isolat menunjukkan hasil ekstrak bawang dayak mempunyai aktivitas antibakteri yang tergolong moderat/sedang terhadap B. subtilis, S. aureus, dan $K$. pneumoniae, ditunjukkan dengan nilai KHM antara 100-200 $\mu \mathrm{g} / \mathrm{ml}$. Sementara senyawa isolat (Hongconin) mempunyai aktivitas antibakteri yang tergolong lemah terhadap semua jenis bakteri patogen yang diujikan, ditunjukkan dengan nilai $\mathrm{KHM}>200 \mu \mathrm{M}$.

4. Penelitian tentang isolasi senyawa bioaktif dari ekstrak bawang dayak perlu dilakukan untuk mencari senyawa yang bertanggung jawab atas efek antibakterinya. Selanjutnya, senyawa tersebut perlu dikembangkan menjadi kandidat antibiotik baru untuk mengatasi berbagai penyakit infeksi.

\section{REFERENCES}

1. Okeke, I.N., Laxminarayan, R., Bhutta, Z.A., Duse, A.G., Jenkins, P., O’Brien, T.F., Pablos-Mendez, A., Klugman, K.P. 2005. Antimicrobial resistance in developing countries. Part I: Recent trends and current status. The Lancet Infectous Disease. 5, 481-493.

$\begin{array}{lllllll}2 . & \text { Kemenkes RI. } 2020 . & \text { Profil } & \text { Kesehatan }\end{array}$ https://www.kemkes.go.id/folder/view/01/structure-publikasi-pusdatin-profil-kesehatan.html, diakses tanggal 24 Januari 2021.

3. Uche-Okereafor, Nkemdinma, Sebola, M., Tapfuma, K., Mekuto, L., Green, E., Mavungmengwana, V. 2019. Antibacterial Activities of Crude Secondary Metabolite Extracts from Pantoea Species Obtained from the Stem of Solanum mauritianum and Their Effects on Two Cancer Cell Lines. International Jurnal of Environmental Research and Public Health. 16, 602.

4. Reichling, J. 2010. Plant-microbe interactions and secondary metabolites with antibacterial, antifungal, and antiviral properties, in Annual Plant Reviews volume 39: functions and biotechnology of plant secondary metabolites: Wiley-Blackwell Publishing, Iowa, USA, 2nd edition, pp 214-317.

5. Hussain H, Al-Harrasi A, Abbas G, Rehman NU, Mabood F, Ahmed I, Saleem M, Van Ree T, Green IR, Anwar S, Badshah A, Shah A, Ali I., 2013, The Genus Pluchea :Phytochemistry,Traditional Uses, and Biological Activities. Chemistry and Biodiversity, 10, 1944-1971.

6. Dalimartha S., 2000, Atlas Tumbuhan Obat Indonesia. Trubus Agriwidya, Jakarta.

7. Siregar R.M., 2015, Antibacterial Activity of Kitolod (Laurentia longiflora (L). Peterm) Leaf and Flower Extact Against Several Conjunctivity Causing Bacteria, Institut Pertanian Bogor, 1 (L), 8.

8. Banso A., 2009, Phytochemical and antibacterial investigation of bark extracts of Acacia nilotica, Journal of Medicinal Plants Research, 3, 82-85

9. Naumann H.D., Tedeschi L.O., Zeller W.E., Huntley N.F., 2017, The role of condensed tannins in ruminant animal production: advances, limitations and future directions, Brazilian Journal of Animal Science 46(12): 929-949.

10. Kumar, S., and Pandey A.K., 2013, Chemistry and Biological Activities of Flavonoids: An Overview, The Scientific World Journal, 1, 1-16.

11. Nitiema, L.W., Savadogo, A., Simpore, J., Dianou, D., Traore, A.S., 2012, In vitro Antimicrobial Activity of Some Phenolic Compounds (Coumarin and Quercetin) Against Gastroenteritis Bacterial Strains, International Journal of Microbiological Research 3(3): 183-187.

12. Malekinejad, H.; Gilani, B. B.; Tukmechi, A.; Ebrahimi, H. A cytotoxicity and comparative antibacterial study on the effect of Zataria multiflora Boiss, Trachyspermum copticum essential oils, and Enrofloxacin on Aeromonas hydrophila. Avicenna J. Phytomed. 2012, 2, 188-195.

13. Fernandes, R.A., Chavan, V.P., 2010, A Concise Asymmetric Synthesis of (-)-Hongconin and (-) -1-epi-Hongconin, European Journal of Organic Chemistry, 22, 4306-4311.

14. Zhengxiong, C., Huizhu, H., Chengrui, W., Yuhui, L., Jianmi,D., Sankawa U., Noguchi H. and Itaka Y., 1986, Hongconin, a New Naphthalene Derivative from Hong-Cong, the Rhizome of Eleutherine ameicana MERR. et HEYNE (Iridaceae), Chem. Pharm. Bull., 34(7): 2743-2746.

15. Kuete, V., 2010, Potential of Cameroonian plants and derived products against microbial infections: a review, Planta Medica, 76(14): 1479-1491.

16. Salton, M.R.J.; Kim, K.S. Structure. In Medical Microbiology, 4th ed.; Baron, S., Ed.; University of Texas Medical Branch at Galveston: Galveston TX, USA, 1996; Chapter 2; https://www.ncbi.nlm.nih.gov/ books/NBK8477/, diakses tanggal 22 Januari 2021.

17. Insanu, M., Kusmardiyani, S., Hartati, R., 2014, Recent Studies on Phytochemicals and Pharmacological Effects of Eleutherine americana Merr., Procedia Chemistry 13, 221-228.

18. Ifesan, B.O., Hamtasin, C., Mahabusarakam, W., Voravuthikunchai S.P., 2009, Assessment of antistaphylococcal activity of partially purified fractions and pure compounds from Eleutherine 
Americana, Journal of Food Protection, 72(2): 354-359.

19. Balouiri, M.; Sadiki, M.; Ibnsouda, S, K., 2016, Methods for in vitro evaluating antimicrobial activity: a review, Journal of Pharmaceutical Analysis, 6, 71-79.

20. Grela, E., Kozłowska, J., Grabowlecka, A., 2018, Current methodology of MTT assay in bacteria - A review, Acta Histochemica, 120(4):303-311.

21. Ieyama T, Gunawan-Puteri MDPT, Kawabata J, 2011, a-Glucosidase inhibitors from the bulb of Eleutherine Americana, Food Chemistry, 128, 308-311

22. Sirirak T, SP. Voravuthikunchai, 2011, Eleutherine americana: A candidate for the control of Campylobacter species. Poultry Science, 90, 791-796.

23. Ifesan B.O., Joycharat N., Voravuthikunchai, S.P., 2009, The mode of antistaphylococcal action of Eleutherine americana. FEMS Immunology and Medical Microbiology, 57, 193-201.

24. Caamal-Fuentes, E.E., Peraza-Sanchez, S.R., Torres-Tapia, L.W., Moo-Puc, R.E., 2015, Isolation and Identification of Cytotoxic Compounds from Aeschynomene fascicularis, a Mayan Medicinal Plant, Molecules, 20(8), 13563-13574.

25. Meletiadis, J., Meis, J.F.G.M., Mouton, J.W., 2001, Analysis of growth characteristics of filamentous fungi in different nutrient media, Journal of Clinical Microbiology, vol 39, pp. 478-484. 